\title{
PEMBUATAN BIODIESEL DARI MINYAK DEDAK PADI DENGAN REAKSI TRANSESTERIFIKASI MENGGUNAKAN KATALIS HETEROGEN ZEOLIT ALAM YANG DIMODIFIKASI DENGAN KOH
}

\author{
BIODIESEL PRODUCTION FROM RICE BRAN OIL BY \\ TRANSESTERIFICATION USING HETEROGENEOUS CATALYST \\ NATURAL ZEOLITE MODIFIED WITH KOH
}

\author{
Taslim*, Sri Zahrani Dwi Mauliyah Parinduri, Putri Retno Wahyu Ningsih \\ Departemen Teknik Kimia, Fakultas Teknik, Universitas Sumatera Utara, Jalan Almamater Kampus USU, \\ Medan, 20155, Sumatera Utara, Indonesia \\ *Email: taslim_hr@yahoo.co.id
}

\begin{abstract}
Abstrak
Biodiesel biasanya dibuat dari reaksi transesterifikasi minyak/lemak menggunakan alkohol. Pada penelitian ini minyak dedak padi digunakan sebagai bahan baku dan metanol digunakan sebagai pereaksi. Reaksi transesterifikasi dari minyak dedak padi menggunakan $\mathrm{KOH} /$ zeolit alam sebagai katalis heterogen padat. Tujuan dari penelitian ini adalah untuk mengetahui keefektifan dari penggunaan zeolit alam yang dimodifikasi dengan $\mathrm{KOH}$ sebagai katalis heterogen pada pembuatan biodiesel dari minyak dedak padi. Katalis $\mathrm{KOH} /$ zeolit alam disiapkan dengan modifikasi melalui metode impregnasi yang dilakukan dengan variasi jumlah larutan $\mathrm{KOH}$ (75 gram/100 ml-175 gram $/ 100 \mathrm{ml}$ ). Reaksi transesterifikasi dilakukan pada suhu $60{ }^{\circ} \mathrm{C}, 500 \mathrm{rpm}$ dan variasi proses diantaranya jumlah katalis (2-4\%), waktu (1,5-3,5 jam), dan rasio mol metanol dengan minyak (8:1-12:1). Yield biodiesel terbaik sebesar $98,71 \%$ yang diperoleh pada kondisi operasi jumlah katalis $2 \%$, waktu reaksi 2 jam, dan rasio mol metanol dengan minyak 10:1. Zeolit alam sebagai katalis heterogen yang dimodifikasi dengan $\mathrm{KOH}$ dapat memberikan yield biodiesel yang lebih tinggi pada reaksi transesterifikasi.
\end{abstract}

Kata kunci: Biodiesel, dedak padi, zeolit alam, $\mathrm{KOH}$, transesterifikasi

\begin{abstract}
Biodiesel was usually produced from transesterification using alchohol. In this research rice bran oil was used as feedstock and methanol was used as reagent. The transesterification of rice bran oil had studied using KOH/natural zeolite as a solid heterogeneous catalyst. The objective of this study was to discover the effectivess of using natural zeolite modified by $\mathrm{KOH}$ as heterogeneous catalysts in the production of biodiesel from rice bran oil (RBO). KOH/natural zeolite catalyst was prepared by modification through impregnation method which was conducted on various $\mathrm{KOH}$ concentration (75 gram $/ 100 \mathrm{ml}-175 \mathrm{gram} / 100 \mathrm{ml}$ ). Transesterification reaction was conducted at $60{ }^{\circ} \mathrm{C}, 500$ rpm, and various amount of catalyst (2-4\%), reaction time (1,5-3,5 hour) and molar ratio alcohol/oil (8:1-12:1). The highest yield of biodiesel was $98,71 \%$, which was obtained by using $2 \%$ catalyst, reaction time 2 hour, molar ratio alcohol/oil 10:1. Natural zeolite as heterogeneous catalyst which modified by $\mathrm{KOH}$ could get the higher yield biodiesel on transesterification.
\end{abstract}

Keywords: biodiesel, rice bran oil, $\mathrm{KOH}$, transesterification

\section{Pendahuluan}

Indonesia memiliki tingkat konsumsi bahan bakar minyak terbesar sebagai sumber energi. Data menyebutkan bahwa konsumsi minyak di Indonesia mencapai 363,52 million BOE (Barrel of Oil Equivalent), angka ini mendekati $36,41 \%$ dari total konsumsi energi yaitu sebesar 998,53 million BOE (Barrel of Oil Equivalent) [21]. Peningkatan pertumbuhan populasi manusia dan pertumbuhan industri akan meningkatkan konsumsi energi [5].

Bahan bakar fosil (pertoleum) yang digunakan secara terus - menerus akan mengikis persediaannya bahan bakar minyak di dalam bumi.
Keterbatasan bahan bakar fosil inilah yang dapat meningkatkan harga minyak naik sehingga diperlukan energi alternatif untuk dapat memenuhi konsumsi energi [16]. Biodiesel merupakan bahan bakar alternatif yang dapat digunakan sebagai pengganti bahan bakar bakar fosil [10].

Biodiesel memiliki banyak kelebihan dibandingkan bahan bakar fosil diantaranya: lebih ramah lingkungan dengan mengurangi jumlah polutan (CO) yang dihasilkan, memiliki titik nyala yang tinggi, merupakan energi yang bersifat 
biodegradable, serta mengurangi senyawasenyawa toksik [16,20].

Penggunaan bahan pangan berupa minyak nabati sebagai bahan baku biodiesel akan menggangu kesetimbangan ketahanan pangan [5,18]. Selain itu, harga jual minyak dari bahan pangan akan lebih tinggi jika dimanfaatkan sebagai biodiesel serta menyebabkan krisis laju produksi bahan minyak pangan [17]. Oleh karena itu, pemanfaatan bahan bukan pangan yang berupa dedak padi sebagai biodiesel sangat dianjurkan karena tidak akan menganggu, lebih bersifat ekonomis dan tidak menjadikan kelangkaan pada bahan pangan.

Biodiesel dari minyak dedak padi sangat berpotensi dalam pengaplikasiannya di Indonesia. Hal ini dibuktikan dengan produksi padi Indonesia pada tahun 2014 (ASEM) sebanyak 70,83 juta ton gabah kering giling (GKG) [7]. Tingginya jumlah produksi tanaman padi di Indonesia menyebabkan banyaknya jumlah limbah dedak padi yang dihasilkan, sehingga memberikan potensi yang besar dalam pemanfaatannya dalam pembuatan biodiesel sebagai sumber energi.

Katalis heterogen memiliki beberapa kelebihan dibandingkan dengan katalis homogen diantaranya memiliki aktivitas katalis yang tinggi pada reaksi transesterifikasi, lebih stabil dan lebih ramah lingkungan, dan mudah dipisahkan [8,23]. Zeolit merupakan katalis heterogen yang memiliki pori - pori dengan ukuran yang sama. Zeolit alam berpotensi digunakan sebagai katalis dalam pembuatan biodiesel, dimana ketersediaannya yang mudah dan murah karena diperoleh dari alam. Penggunaan zeolit dapat diaktivasi dengan memodifikasi untuk memperbesar aktivasinya untuk menghasilkan yield biodiesel yang tinggi. Modifikasi zeolit dilakukan dengan impregnasi senyawa asam atau basa. Dari penelitian sebelumnya disebutkan bahwa impregnasi dengan basa lebih baik dibandingkan dengan asam. Penggunaan katalis zeolit alam sangat berpotensi dalam pembuatan biodiesel [6]. Tujuan dari penelitian ini adalah untuk mengkaji potensi pemanfaatan minyak dedak padi sebagai bahan baku pembuatan biodiesel dan menguji zeolit alam sebagai katalis heterogen dalam reaksi transesterifikasi.

\section{Metodologi Penelitian \\ Bahan Penelitian}

Pada penelitian ini bahan yang digunakan antara lain: minyak dedak padi (RBO) yang di dapatkan dari supermarket di Medan, zeolit alam diperoleh dari PT. Rudang Jaya, serta aquadest $\left(\mathrm{H}_{2} \mathrm{O}\right)$, potassium hidroksida $(\mathrm{KOH})$, metanol $\left(\mathrm{CH}_{3} \mathrm{OH}\right)$, phenolftalein $\left(\mathrm{C}_{20} \mathrm{H}_{14} \mathrm{O}_{4}\right)$, natrium hidroksida $(\mathrm{NaOH})$, hidrogen peroksida $\left(\mathrm{H}_{2} \mathrm{O}_{2}\right)$ $30 \%$.

\section{Peralatan Penelitian}

Gambar 1 menunjukkan rangkaian peralatan yang digunakan dalam penelitian pembuatan katalis modifikasi $\mathrm{KOH} /$ zeolit alam dan biodiesel dari minyak dedak padi.

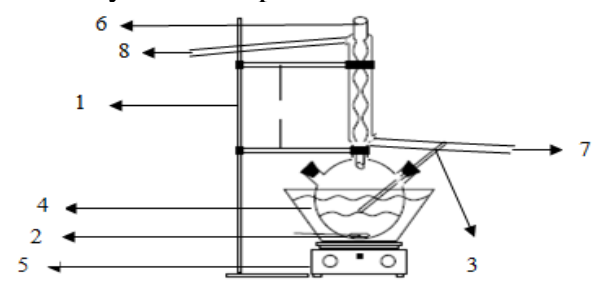

Keterangan gambar

1. Statif dan klem

5. Heater

2. Stirrer

3. Termometer

4. Labu leher tiga

Refluks kondensor

7. Air dingin masuk

8. Air dingin keluar

Gambar 1. Rangkaian Peralatan

\section{Prosedur Penelitian \\ Persiapan Katalis}

Zeolit alam dicuci dengan $30 \% \mathrm{H}_{2} \mathrm{O}_{2}$ untuk menghilangkan impuritisnya, larutan sambil diaduk sampai beberapa menit. Setelah selesai, dihilangkan sisa larutan $\mathrm{H}_{2} \mathrm{O}_{2}$ dengan dipanaskan dalam water bath hingga kering. Zeolit alam kemudian dicuci dengan aquadest dan diulangi hingga bersih. Zeolit dipisahkan dari sisa aquadest dan dikeringkan dalam oven selama 24 jam dengan suhu $110^{\circ} \mathrm{C}$. Zeolit alam yang telah kering digiling dengan mortar agar menghasilkan bubuk zeolit alam dengan ukuran 140 mesh [15].

\section{Modifikasi Katalis KOH/Zeolit Alam sebagai Katalis Basa Kuat}

Zeolit alam diimpregnasi dengan larutan $\mathrm{KOH}$ yang divariasikan konsentrasinya (75 gram/100 ml, 100 gram/100 ml, 125 gram/100 ml, $150 \mathrm{gram} / 100 \mathrm{ml}, 175 \mathrm{gram} / 100 \mathrm{ml}$ ). Zeolit ditimbang dengan berat tertentu dan dilarutkan dalam $100 \mathrm{ml}$ aquadest. Perbandingan massa antara zeolit dengan larutan $\mathrm{KOH}$ adalah 1:4. Proses modifikasi katalis dilakukan dalam labu leher tiga dengan rangkaian peralatan refluks kondensor, termometer dan magnetic stirrer. Larutan $\mathrm{KOH}$ dan zeolit alam dimasukkan ke dalam labu leher tiga. Proses impregnasi katalis dilakukan pada suhu $60^{\circ} \mathrm{C}$ selama 2 jam. Kemudian campuran diletakkan dalam oven dengan suhu $60{ }^{\circ} \mathrm{C}$ selama 24 jam. Setelah proses impregnasi selesai, katalis termodifikasi dipisahkan dengan larutan $\mathrm{KOH}$ dengan vacuum filter. Katalis termodifikasi yang tertahan di kertas saring, selanjutnya akan dikeringkan dengan oven pada suhu $110^{\circ} \mathrm{C}$ selama 24 jam untuk 
menghilangkan kandungan air. Kemudian katalis dikalsinasi pada furnace pada suhu $450^{\circ} \mathrm{C}$ selama 4 jam. Setelah selesai dikalsinasi, katalis $\mathrm{KOH} /$ zeolit alam dihaluskan dengan mortar. Dan katalis $\mathrm{KOH} /$ zeolit dianalisis dengan menggunakan AAS dan FTIR [15].

Proses Transesterifikasi RBO Menggunakan Katalis Heterogen KOH/Zeolit Alam

Metanol dan katalis termodifikasi dengan jumlah variasi tertentu dimasukkan ke dalam labu kemudian dipanaskan hingga $60^{\circ} \mathrm{C}$ sambil diaduk dengan kecepatan pengadukan $500 \mathrm{rpm}$. Secara perlahan-lahan minyak 50 gram dimasukkan ke dalam labu dan reaksi dilangsungkan sesuai variasi waktu yang dilakukan. Setelah reaksi selesai, katalis dipisahkan dari campuran dengan vacuum filter. Campuran hasil reaksi dimasukkan ke dalam corong pemisah dan dibiarkan selama 24 jam hingga terbentuk 2 lapisan. Lapisan bawah yang merupakan metanol dan gliserol dipisahkan dari lapisan atas. Produk biodiesel lapisan atas kemudian dicuci dengan air panas $\left(60^{\circ} \mathrm{C}\right)$ hingga air cucian bersih. Produk biodiesel lapisan atas dipanaskan pada suhu $100^{\circ} \mathrm{C}$ untuk menghilangkan sisa air. Metil ester yang telah kering ditimbang dan dianalisis kandungan metil esternya [15]. Variasi yang dilakukan ditunjukkan dalam Tabel 1.

Tabel 1. Variasi yang dilakukan dalam Transesterifikasi

\begin{tabular}{|l|l|}
\hline Variasi & Rentang \\
\hline Jumlah Katalis (\%) & $2-4$ \\
\hline Waktu Reaksi (jam) & $1,5-3,5$ \\
\hline Rasio molar Metanol/Minyak (n/n) & $8: 1-12: 1$ \\
\hline
\end{tabular}

\section{Analisis Modifikasi Katalis}

Analisis Kadar Logam Kalium

Untuk analisis jumlah kadar logam kalium pada modifikasi katalis ini menggunakan instrumen AAS (Atomic Absorption Spectroscopy).

\section{Analisis Gugus K-O}

Untuk analisis gugus $\mathrm{K}-\mathrm{O}$ pada modifikasi katalis ini menggunakan instrumen FTIR (Fourier Transform Infra Red).

\section{Anlisis Biodiesel}

Analisis Fatty Acid Methyl Ester (FAME)

Komposisi dari masing-masing metil ester ditentukan menggunakan kromatografer gas yang dilengkapi dengan detektor ionisasi api dan injector auto.

\section{Analisis Lainnya}

Densitas, viskositas kinematik, dan titik nyala dari masing-masing metil ester dievaluasi dan dibandingkan dengan standar SNI.

\section{Hasil Dan Pembahasan \\ Hasil Analisis Bahan Baku}

Berdasarkan data hasil analisis GC (Gas Chromatography) yang berupa komposisi asam lemak dari minyak dedak padi dan dentifikasi sifat fisika dari minyak dedak padi dapat dilihat pada Tabel 2 dan 3.

Tabel 2. Komposisi Asam Lemak dari Minyak Dedak Padi

\begin{tabular}{|c|c|c|}
\hline No. Puncak & $\begin{array}{c}\text { Komponen } \\
\text { Penyusun }\end{array}$ & $\begin{array}{l}\text { Komposisi } \\
\text { \% berat }\end{array}$ \\
\hline 1 & $\mathrm{C} 12: 0$ & 0,0114 \\
\hline 2 & $\mathrm{C} 14: 0$ & 0,3912 \\
\hline 3 & $\mathrm{C} 16: 0$ & 20,8620 \\
\hline 4 & $\mathrm{C} 16: 1$ & 0,2638 \\
\hline 5 & $\mathrm{C} 18: 0$ & 2,0197 \\
\hline 6 & $\mathrm{C} 18: 1$ & 42,4643 \\
\hline 7 & $\mathrm{C} 18: 2$ & 32,2081 \\
\hline 8 & $\mathrm{C} 18: 3$ & 1,2199 \\
\hline 9 & $\mathrm{C} 20: 0$ & 0,0522 \\
\hline 10 & $\mathrm{C} 20: 1$ & 0,5074 \\
\hline
\end{tabular}

Tabel 3. Sifat Fisika dari Minyak Dedak Padi

\begin{tabular}{|l|r|}
\hline \multicolumn{1}{|c|}{ Sifat Fisika } & Jumlah \\
\hline Densitas, $\mathrm{kg} / \mathrm{m}^{3}$ & 0,9086 \\
\hline Viskositas, $\mathrm{mm}^{2} / \mathrm{s}$ & 43,0162 \\
\hline FFA, $\%$ & 1,2225 \\
\hline
\end{tabular}

\section{Analisis Kandungan Logam K (Kalium) dengan} AAS

Berikut ini merupakan hasil analisis dengan AAS pada katalis heterogen $\mathrm{KOH} /$ zeolit alam dalam proses impregnasi dapat dilihat pada Gambar 2.

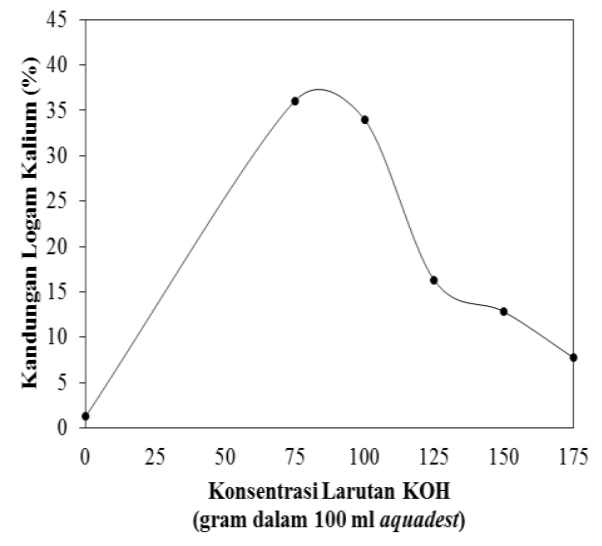

Gambar 2. Hasil Analisis Modifikasi Zeolit Alam dengan AAS 
Gambar 2 menunjukkan bahwa kandungan logam kalium yang paling tinggi terdapat pada konsentrasi larutan $\mathrm{KOH} 75 \mathrm{gram} / 100 \mathrm{ml}$ aquadest yaitu sebesar 36,0473\%. Pada konsentrasi 100 gram $/ 100 \mathrm{ml}$ aquadest terlihat pada grafik kandungan logam kalium semakin menurun hingga konsentrasi larutan $\mathrm{KOH} \quad 175$ gram $/ 100 \mathrm{ml}$ aquadest. Penurunan kandungan logam kalium ini disebabkan oleh semakin tingginya konsentrasi larutan $\mathrm{KOH}$, maka akan membuat larutan $\mathrm{KOH}$ menjadi jenuh atau lewat jenuh.

Dalam penelitian ini $\mathrm{KOH}$ tidak larut sempurna dalam aquadest, dimana senyawa ini memiliki batasan kelarutannya. Adapun hal yang diindikasikan sebagai penyebab penurunan kadar logam kalium pada zeolit alam yaitu, larutan $\mathrm{KOH}$ dapat dikatakan hampir mendekati larutan yang jenuh. Selain itu, ukuran partikel zeolit alam yang mempengaruhi luas permukaan pori dalam penyerapan logam kalium [14]. Ukuran partikel zeolit alam yang digunakan dalam penelitian ini hanya mampu menjerap secara maksimal ion $\mathrm{K}^{+}$ dari konsentrasi larutan $\mathrm{KOH}$ sebesar 75 gram dalam $100 \mathrm{~mL}$ aquadest, sehingga dapat terjadi reaksi balik dimana metode impregnasi ini akan menyebabkan proses pertukaran ion [14]. Dan penyerapan terbaik logam kalium dalam larutan $\mathrm{KOH}$ terlihat pada konsentrasi larutan $\mathrm{KOH} 75$ gram/100 ml aquadest.

\section{Analisis FTIR Zeolit Alam dan Modifikasi KOH/Zeolit Alam}

Hasil terbaiknya pada konsentrasi larutan $\mathrm{KOH}$ sebesar 75 gram/100 ml aquadest yang dilakukan analisis gugus dengan FTIR. Analisis FTIR berguna untuk mengetahui keberadaan gugus $\mathrm{K}-\mathrm{O}$ pada katalis heterogen zeolit alam yang telah dimodifikasi dengan $\mathrm{KOH}$ serta membandingkan dengan gugus zeolit alam tanpa modifikasi. Hal ini disajikan dalam Gambar 3.

Gambar 3 menunjukkan bahwa pada puncak 790,81 $\mathrm{cm}^{-1}$ pada zeolit alam merupakan vibrasi ulur simetri oksida logam. Sedangkan pada $\mathrm{KOH} /$ zeolit alam terlihat pada puncak yang berbeda yaitu $887,26 \mathrm{~cm}^{-1}$. Logam tersebut dapat diidentifikasikan sebagai kalium, karena terjadinya impregnasi zeolit alam dengan larutan $\mathrm{KOH}$ yang mengandung logam kalium. Dengan demikian, pada zeolit alam dan $\mathrm{KOH} /$ zeolit alam terdapat oksida kalium (KO). Munandar, dkk (2014) menyatakan bahwa interval spektra $770-803 \mathrm{~cm}^{-1}$ merupakan interpretasi gugus fungsi K-O [3]. Selain itu, Almjadleh, dkk (2014) melaporkan bahwa pada puncak 750,31 $\mathrm{cm}^{-1}$ terdapat vibrasi ulur simetris oksida logam (MO) serta Ates dan Gokcen (2016) melaporkan bahwa pada kisaran puncak 600-800 $\mathrm{cm}^{-1}$ merupakan ikatan dari pertukaran kation $[1,13]$.
Oleh karena itu, dapat diindifikasikan bahwa pada puncak serapan ini terdapat gugus dari kation $\mathrm{K}^{+}$yang berikatan dengan kerangka utama zeolit alam, baik itu $\mathrm{Si}-\mathrm{O}-\mathrm{K}$ atau $\mathrm{Al}-\mathrm{O}-\mathrm{K}$. Keberadaan puncak ini pada zeolit alam menjadi bagian penting dari keaktifan katalitik zeolit alam sebagai katalis dalam reaksi. Selain itu, dapat dilihat bahwa pada $\mathrm{KOH} /$ zeolit alam memiliki puncak yang lebih kuat pada gugus serapan 887,26 $\mathrm{cm}^{-1}$ yang mengindifikasikan gugus kalium dibandingkan pada zeolit alam yang memiliki puncak yang lebih lemah.

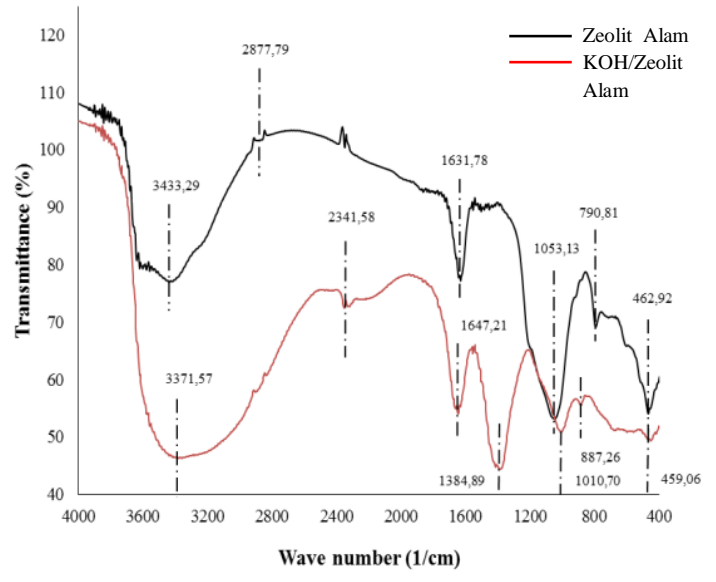

Keterangan analisis gugus fungsi :

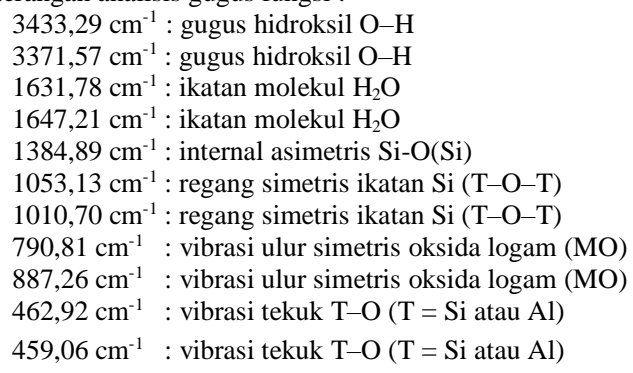

Gambar 3. Hasil Analisis Modifikasi Zeolit Alam dengan FTIR

Hal ini membuktikan bahwa kandungan kalium pada $\mathrm{KOH} /$ zeolit alam lebih besar dari zeolit alam tanpa modifikasi. Pada beberapa puncak gugus serapan $\mathrm{KOH} /$ zeolit alam mengalami sedikit perubahan yaitu penurunan intensitas gelombang. Hal ini disebabkan karena dalam proses impregnasi terjadi dekationisasi sebagai desilikasi dan hilangnya sifat mengkristal, seperti yang dinyatakan oleh Ates dan Gokcen [1].

\section{Pengaruh Variabel Percobaan Terhadap Yield Biodiesel Pada Proses Transesterifikasi}

Pada pembuatan biodiesel dengan menggunakan katalis zeolit alam tanpa modifikasi menghasilkan yield biodiesel sebesar 6,25\%. Oleh karena itu, pembuatan biodiesel dengan katalis zeolit alam yang dimodifikasi dengan $\mathrm{KOH}$ dapat meningkatkan yield biodiesel, berikut merupakan 
pengaruh variabel percobaan terhadap yield biodiesel.

\section{Pengaruh Jumlah Katalis KOH/Zeolit Alam terhadap Yield Biodiesel}

Gambar 4 menunjukkan variasi jumlah katalis pada suhu $60{ }^{\circ} \mathrm{C}$, rasio mol 10:1 dan waktu reaksi 2 jam. Pada reaksi transesterifikasi minyak dan metanol dengan katalis $\mathrm{KOH} /$ zeolit alam sebesar 2\% memiliki laju yang tinggi. Hal ini dibuktikan dengan lapisan metil ester telah banyak terbentuk pada jumlah katalis $2 \%$ dan besarnya massa metil ester yang dihasilkan. Akan tetapi, pada reaksi transesterifikasi dengan penambahan jumlah katalis $\mathrm{KOH} /$ zeolit alam setelah $2 \%$ tidak meningkatkan yield biodiesel. Penambahan jumlah katalis ini tidak dapat meningkatkan yield biodiesel disebabkan adanya keterbatasan perpindahan massa dan tingginya viskositas pada campuran reaksi.

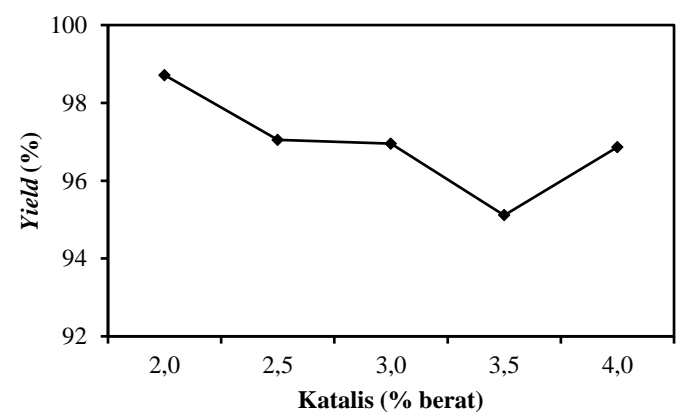

Gambar 4. Hubungan antara Jumlah Katalis dengan Yield Biodiesel pada Kondisi Suhu Reaksi $60^{\circ} \mathrm{C}$, Waktu 2 Jam, dan Perbandingan Mol Alkohol/Minyak 10:1

Pada reaksi dengan katalis heterogen, metoksida dibentuk pada permukaan katalis, dimana pada proses ini bergantung pada perpindahan massa dari metanol terhadap katalis $[9,19$,$] . Keterbatasan perpindahan massa yang$ terjadi inilah akan mempersulit pencampuran dari reaktan dan menurunkan yield biodiesel. Hal ini ditunjukkan pada penambahan katalis $\mathrm{KOH} /$ zeolit alam setelah $2 \%(2,5 ; 3 ; 3,5 ; 4)$ cenderung mengalami penurunan yield biodiesel.

Pada penelitian ini diperoleh yield tertinggi pada jumlah katalis 2\%, hal ini lebih baik dibandingkan yang telah dilaporkan oleh Kusuma, $\mathrm{dkk}$ [15] dengan perolehan yield tertinggi $(95,06 \%)$ pada jumlah katalis 3\% tetapi menggunakan minyak kelapa sawit.

\section{Pengaruh Waktu Reaksi terhadap Yield Biodiesel}

Gambar 5 menunjukkan variasi waktu reaksi pada suhu $60^{\circ} \mathrm{C}$, rasio mol 10:1 dan jumlah katalis 2\% dapat dilihat sebagai berikut. Pada reaksi awal transesterifikasi minyak dedak padi dan metanol dengan katalis $\mathrm{KOH} /$ zeolit alam akan berjalan secara perlahan untuk mendispersikan minyak dan alkohol [2]. Selanjutnya reaksi transesterifikasi akan berjalan cepat hingga menghasilkan yield biodiesel yang terbaik [22].

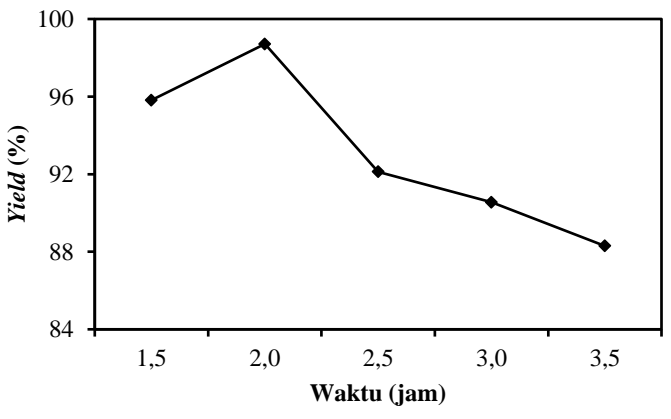

Gambar 5. Hubungan antara Waktu Reaksi dengan Yield Biodiesel pada Kondisi Suhu Reaksi $60^{\circ} \mathrm{C}$, Jumlah Katalis $2 \%$, dan Perbandingan Mol Alkohol/Minyak 10:1

Hal ini dapat dilihat terjadi peningkatan yield biodiesel dari $95,82 \%$ hingga $98,71 \%$ yang dihasilkan dari waktu reaksi 1,5 jam hingga 2 jam. Pada reaksi transesterifikasi dengan waktu reaksi 2 jam inilah menghasilkan yield biodiesel yang terbaik. Setelah waktu reaksi 2 jam yield biodiesel mengalami penurunan. Hal ini disebabkan reaksi transesterifikasi merupakan reaksi reversible. Waktu reaksi yang terlalu lama akan mengakibatkan reaksi balik [9]. Reaksi balik pada transesterifikasi akan menghasilkan asam lemak dan akan mengurangi yield FAME yang dihasilkan [12]. Hal ini dapat ditunjukkan bahwa pada waktu reaksi setelah 2 jam $(2,5 ; 3 ; 3,5$ jam $)$ mengalami penurunan yield biodiesel dari $98,71 \%$ hingga $88,30 \%$.

Pada penelitian ini diperoleh yield tertinggi pada waktu reaksi 2 jam. Hasil yang sama juga telah dilaporkan oleh Kusuma, dkk [15] dengan perolehan yield tertinggi $(95,06 \%)$ pada waktu reaksi 2 jam tetapi menggunakan minyak kelapa sawit.

\section{Pengaruh Rasio Mol Alkohol/ Minyak terhadap Yield Biodiesel}

Gambar 6 menunjukkan variasi perbandingan mol alkohol /minyak pada suhu 60 ${ }^{\circ} \mathrm{C}$ dan waktu reaksi 2 jam. Pada dasarnya penggunaan rasio molar metanol/minyak yang berlebih akan mengeser reaksi ke arah equilibrium reaksi dan membantu mencapai yield biodiesel yang terbaik [22]. Hal ini ditunjukkan terjadinya peningkatan yield biodiesel pada perbandingan mol alkohol/minyak 8:1 hingga perbandingan mol alkohol/minyak 10:1 dari masing-masing variasi 
katalis 2, 3, dan 4\%. Dan pada perbandingan mol alkohol/minyak 10:1, reaksi transesterifikasi telah bergeser pada kesetimbangan reaksi dan mencapai yield terbaik pada masing-masing variasi katalis.

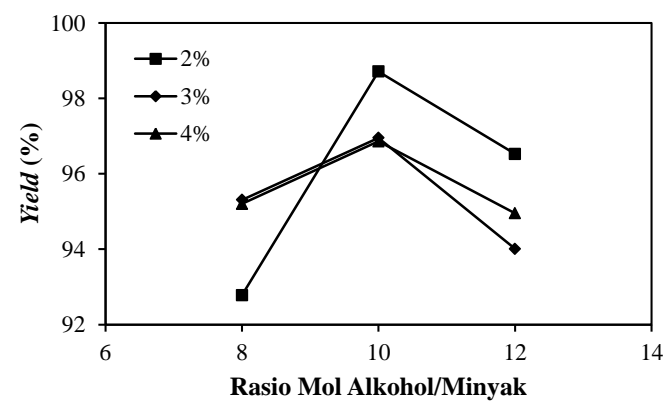

Gambar 6. Hubungan antara Rasio Mol, Alkohol/Minyak dengan Yield Biodiesel pada Kondisi Suhu Reaksi $60{ }^{\circ} \mathrm{C}$, Waktu Reaksi 2 jam, serta Jumlah Katalis 2, 3 dan 4\%

Penggunaan rasio molar metanol/minyak yang terlalu tinggi akan melarutkan gliserol sebagai reaksi samping dengan kelebihan metanol, sehingga dapat menghalangi reaksi metanol, minyak dan katalis. Selain itu, gugus polar hidroksil metanol akan menjadi emulsifier yang akan mengakibatkan semakin sulit proses pemisahan biodiesel dari campuran hasil reaksi sehingga akan menggurangi \% yield FAME [19]. Hal ini ditunjukkan terjadinya penurunan yield biodiesel dari perbandingan mol alkohol/minyak 10:1 hingga perbandingan mol alkohol/minyak $12: 1$ pada masing-masing variasi katalis 2,3 , dan $4 \%$.

Pada penelitian ini diperoleh yield tertinggi pada rasio molar 10:1, hal ini lebih besar dibandingkan dengan Kusuma, dkk [15] dengan perolehan yield tertinggi $(95,06 \%)$ pada rasio molar 7:1 tetapi menggunakan minyak kelapa sawit.

\section{Karakteristik Biodiesel}

Karakteritik biodiesel merupakan sifat fisik dan atau sifat kimia yang dimiliki oleh biodiesel. Standar karakteritik biodiesel dapat dilihat berdasarkan standar ASTM D6751 dan SNI yang dapat dilihat pada Tabel 4 berikut.

Karakteristik biodiesel meliputi densitas, viskositas kinematik, kandungan ester, dan titik nyala. Kontaminasi dari biodiesel dapat mempengaruhi densitasnya, oleh karena itu densitas dapat dijadikan indikator dari kontaminan. Biodiesel memiliki sifat lebih polar dari bahan bakar diesel sehingga viskositas biodiesel lebih tinggi dari bahan bakar diesel. Titik nyala berbanding terbalik dengan volatilitas bahan bakar. Titik nyala biodiesel semakin rendah dengan adanya sisa alkohol yang tidak bereaksi [11].
Dari hasil uji beberapa karakteristik biodiesel yang dihasilkan, dapat dilihat bahwa biodiesel telah memenuhi standar SNI dan ASTM. Hal ini menunjukkan penggunaan katalis modifikasi zeolit alam dengan $\mathrm{KOH}$ dalam proses transesterifikasi dapat menghasilkan karakteristik biodiesel yang sesuai dengan standar.

Tabel 4 Karakteristik Biodiesel [4]

\begin{tabular}{|l|l|l|l|l|}
\hline Parameter & Unit & Nilai & $\begin{array}{l}\text { Standar } \\
\text { ASTM } \\
\text { D6751 }\end{array}$ & $\begin{array}{l}\text { Stand } \\
\text { ar } \\
\text { SNI }\end{array}$ \\
\hline $\begin{array}{l}\text { Ester } \\
\text { Content }\end{array}$ & $\begin{array}{l}\% \\
(\mathrm{~m} / \mathrm{m})\end{array}$ & 98,7673 & - & $>96,5$ \\
\hline $\begin{array}{l}\text { Densitas } \\
\text { pada } 40{ }^{\circ} \mathrm{C}\end{array}$ & $\mathrm{kg} / \mathrm{m}^{3}$ & 867,4969 & - & $\begin{array}{l}850- \\
900\end{array}$ \\
\hline $\begin{array}{l}\text { Viskositas } \\
\text { kinematik } \\
\text { pada } 40{ }^{\circ} \mathrm{C}\end{array}$ & $\mathrm{mm}^{2} / \mathrm{s}$ & 4,5486 & $3,5-5$ & $2,3-6$ \\
\hline Flash Point & ${ }^{\circ} \mathrm{C}$ & 152 & $>130$ & 100 \\
\hline
\end{tabular}

\section{Kesimpulan}

Zeolit alam yang dimodifikasi dengan $\mathrm{KOH}$ dapat digunakan sebagai katalis heterogen dalam pembuatan biodiesel dan memberikan yield biodiesel yang tinggi dibandingkan dengan zeolit alam tanpa modifikasi. Dari hasil penelitian, yield terbaik diperoleh sebesar $98,71 \%$ pada jumlah katalis $2 \%$, waktu reaksi 2 jam, perbandingan alkohol/minyak $10: 1$, suhu $60^{\circ} \mathrm{C}$, dan kecepatan pengadukan $500 \mathrm{rpm}$. Biodiesel yang diperoleh telah sesuai dengan Standar Nasional Indonesia (SNI).

\section{Daftar Pustaka}

[1] A. Ates dan G. Akgul, Modification of Natural Zeolite with $\mathrm{NaOH}$ for Removal of Manganese in Drinking Water, Elsevier. Powder Technology, 287, (2016), 285-291.

[2] A. Gashaw dan A. Teshita, Production of Biodiesel from Waste Cooking Oil and Factors Affecting Its Formation: A Review, International Journal of Renewable and Sustainable Energy, 3, (2014), 92-98.

[3] A. Munandar, D. Krisdiyanto, Khamidinal dan P. Artsanti, Adsorpsi Logam $\mathrm{Pb}$ dan $\mathrm{Fe}$ dengan Zeolit Alam Teraktivasi Asam Sulfat, UIN Sunan Kalijaga, Yogyakarta. Seminar Nasional Kimia dan Pendidikan Kimia VI, (2014), ISBN : 979363174-0.

[4] A. O. Mopelola dan O. A. Akinsanoye, A Review of Biodiesel Generation From Non Edible Oil Seed Oils Crop Using Conventional Heterogeneous Catalysts, Journal of Petroleum Technology and Alternative Fuels, ISSN 2360-8560, 6, (2015), 1-12.

[5] A. S. Reshad, P. Tiwari dan V. V. Goud, Extraction of Oil from Rubber Seeds for 
Biodiesel Application: Optimization of Parameters, Elsevier. Fuel, 150, (2015), 636644.

[6] A. S. Utomo, Preparasi $\mathrm{NaOH} /$ Zeolit sebagai Katalis Heterogen untuk Sintesis Biodiesel dari Minyak Goreng Secara Transesterifikasi,. Skripsi Program Studi Teknik Kimia. Depok : Universitas Indonesia. 2011.

[7] BPS. 2015. "Padi". www.bps.go.id. Diakses pada tanggal 26 Juni 2015.

[8] C. Samart, S. Karnjanakom, C. Chaiya, P. Reubroycharoen, R. Sawangkeaw, dan M. Charoenpanich, Statistical Optimization of Biodiesel Production from Para Rubber Seed Oil by $\mathrm{SO}_{3} \mathrm{H}-\mathrm{MCM}-41$ Catalyst. Elsevier. Arabian Journal Of Chemistry (In Press). 2015.

[9] G. Y. Chen, R. Shan, B. B. Yan, J. F. Shi, S. Y. Li, dan C. Y. Liu, Remarkably Enchancing the Biodiesel Yield from Palm Oil Upon Abalone Shell Derived $\mathrm{CaO}$ Catalysts Treated by Ethanol, Elsevier. Fuel Processing Technology, 143, (2016), 110-117.

[10]H. R. Ong, M. R. Khan., M. N. K. Chowdhury, A. Yousuf, dan C. K. Cheng, Synthesis and Characterization of $\mathrm{Cuo} / \mathrm{C}$ Catalyst for the Esterification of Free Fatty Acid in Rubber Seed Oil, Elsevier. Journal Fuel, 120, (2014), 195-201.

[11] I. Barabaas dan I. A. Todorut, Biodiesel Quality, Standards and Properties, BiodieselQuality, Emissions and By-Products,. Technical University of Cluj-Napoca, Romania. (2011).

[12]I. Boumesbah, Z. H. Sadouk, dan A. Tazerouti, Biodiesel Production from Waste Frying Oil and Determination of Fuel Properties, Revue des Energies Renouvelables SIENR'14 Ghardaïa, (2014), 109-113.

[13] M. Almjadleh, S. Alasheh, dan I. Raheb. Use of Natural and Modified Jordanian Zeolitic Tuff for Removal of Cadmium(II) from Aqueous Solutions. Jordan Journal of Civil Engineering, 8, (2014).

[14]R. H. Perry dan D. W. Green. Chemical Engineering HandBook. $7^{\text {th }}$ Edition. New York: McGraw-Hill Book Company. 1997.

[15] R. I. Kusuma, J. P. Hadinoto, A. Ayucitra, F. E. Soetaredjo, dan S. Ismadji. Natural Zelite from Pacitan Indonesia, as Catalysts Support for Transesterification of Palm Oil, Elsevier. Widya Mandala Surabaya University, Surabaya, Indonesia, Applied Clay Science, 74, (2013), 121-126.

[16] R. Yang, M. Su, J. Zhang, F. Jin, C. Zha, M. Li, dan X. Hao, Biodiesel Production from Rubber Seed Oil Using Poly (Sodium Acrylate) Supporting $\mathrm{NaOH}$ as a Water-
Resistant Catalyst, Elsevier. Bioresource Technology, 102, (2011), 2665-2671.

[17] S. S. Kumar, dan K. Purushothaman, High FFA Rubber Seed Oil as an Alternative Fuel for Diesel Engine-An Overview, Anna University, Chennai, India . Research Inventy: International Journal of Engineering and Science ISBN: 2319-6483, ISSN: 2278-4721, Vol. 1, Issue 10 (December 2012), 16-24.

[18] S. Yusup dan M. Khan, Basic Properties of Crude Rubber Seed Oil and Crude Palm Oil Blend as a Potential Feedstock for Biodiesel Production with Enhanced Cold Flow Characteristics, Elsevier. Biomass and Bioenergy, 34, (2010), 1523-1526.

[19] W. Roschat, T. Siritanon, B. Yoosuk, dan V. Promarak, Risk Husk Derived Sodium Silicate as a Highly Efficient and Low Cost Basic Heterogenous Catalyst for Biodiesel Production, Elsevier. Energy Conversion and Management, 119, (2016), 453-462.

[20] W. Widayat dan S. Suherman, Biodiesel Production from Rubber Seed Oil via Esterification Process, Chemical Engineering Department, Faculty of Engineering, Diponegoro University, Semarang. Int. Journal of Renewable Energy Development, 1, (2012), 57-60.

[21] Widayat, A. D. K. Wibowo, dan Hadiyanto, Study on Production Process of Biodiesel from Rubber Seed (Hevea Brasiliensis) by In Situ (Trans)Esterification Method with Acid Catalyst, Chemical Engineering, Diponogoro University, Semarang. Journal Energy Procedia, 32, ( 2013), 64-73.

[22] Y. H. Tan, M. O. Abdullah, C. N. Hipolito, dan Y. H. T. Yap, Waste Ostrich and Chicken Eggshell as Heterogeneous Base Catalyst for Biodiesel Production from Used Cooking Oil: Catalyst Characterization and Biodiesel Yield Performance, Elsevier. Applied Energy, 160, (2015), 58-70.

[23] Y. Syamsuddin dan H. Husin, Pembuatan Katalis Padat $\mathrm{ZrO}_{2} / \mathrm{Al}_{2} \mathrm{O}_{3}$ untuk Produksi Biodiesel dari Minyak Jarak, Jurusan Teknik Kimia, Fakultas Teknik, Universitas Syiah Kuala. Jurnal Rekayasa Kimia dan Lingkungan, ISSN 1412-5064, 7, (2010), 112117. 